Tasharruf: Journal Economics and Business of Islam Vol. 6, No. 1 (2021):31-43

Website: http://journal.iain-manado.ac.id/index.php/TJEBI/index

ISSN 2528-0325 (online) ISSN 2528-0317 (print)

\title{
SUKUK RATING AND FINANCIAL RATIO IN ISLAMIC BANKS
}

\author{
Kurnia Agustina \\ Pascasarjana UIN Raden Intan Lmpung, Jl. Yulius Usman No.20, Labuhan Ratu, Kec. Kedaton, \\ Kota Bandar Lampung, Lampung 35132 \\ Email80808nia@gmail.com \\ Heni Noviarita \\ Fakultas Ekonomi dan Bisnis Islam UIN Raden Intan Lampung, Jl. Letnan Kolonel H Jl. Endro \\ Suratmin, Sukarame, Kec. Sukarame, Kota Bandar Lampung, Lampung 35131 \\ Email heninoviarita@radenintan.ac.id \\ Erike Anggraini \\ Fakultas Ekonomi dan Bisnis Islam UIN Raden Intan Lampung, J1. Letnan Kolonel H J1. Endro \\ Suratmin, Sukarame, Kec. Sukarame, Kota Bandar Lampung, Lampung 35131 \\ Email erikeanggraini@,radenintan.ac.id \\ Surono \\ Fakultas Ekonomi dan Bisnis Islam UIN Raden Intan Lampung, J1. Letnan Kolonel H Jl. Endro \\ Suratmin, Sukarame, Kec. Sukarame, Kota Bandar Lampung, Lampung 35131 \\ Email Surono@,radenintan.ac.id
}

\begin{abstract}
The sukuk rating in capital market world is important because it will be considered by investors in determining investment decisions, on the other hand, that the rating will provide relevant information regarding the companies that issue sukuk, which will be in accordance with the main purpose of the sukuk rating, namely reducing the information asymmetry of issuers and investors purpose of this study is to discuss the effect of profitability ratios, liquidity ratios, leverage and productivity ratios on sukuk ratings in Islamic banking institutions issuing sukuk. By using purposive sampling from 14 Islamic banking institutions, 6 Islamic bank institutions were obtained as research samples in the 2015-2019 period, which were analyzed using multiple linear regression showing that only the productivity variable had a significant and positive influence on the rating of sukuk in Islamic banking institutions, although, with a positive coefficient, profitability does not have a significant effect on the sukuk rating, while the liquidity and leverage variables do not have a significant effect and form a negative relationship pattern on the sukuk rating in Indonesian Islamic banking institutions that issue sukuk.
\end{abstract}

Keywords: Islamic Banks; Sukuk Rating; Financial Ratios.

Sukuk Rating and Financial Ratio on Islamic Banks 


\title{
Tasharruf: Journal Economics and Business of Islam Vol. 6, No. 1 (2021):31-43 \\ Website: http://journal.iain-manado.ac.id/index.php/TJEBI/index \\ ISSN 2528-0325 (online) ISSN 2528-0317 (print)
}

\begin{abstract}
ABSTRAK
Rating sukuk dalam dunia pasar modal menjadi penting karena akan menjadi pertimbangan investor dalam menentukan keputusan investasi, disisi lain bahwa rating tersebut akan memberi informasi yang relevan terkait perusahaan yang mengeluarkan sukuk, dimana ini akan sesuai dengan tujuan utama dilakukannya pemeringkatan sukuk yaitu mengurangi asimetri informasi emiten dan investorTujuan penelitian ini yaitu untuk membahas pengaruh rasio profitabilitas, rasio likuiditas, leverage dan rasio produktivitas terhadap peringkat sukuk di lembaga perbankan syariah penerbit sukuk. Dengan menggunakan purposive sampling dari 14 perbankan syariah didapat 6 lembaga bank syariah sebagai sampel penelitian dalam kurun waktu 2015-2019, yang dianalisis menggunakan regresi linier berganda menunjukkan bahwa hanya variable produktivitas yang mempunyai pengaruh yang signifikan dan positif terhadap peringkat sukuk di lembaga perbakan syariah, meskipun berkoefisien positif, profitabilitas tidak memiliki pengaruh yang signifikan terhadap peringkat sukuk, sedangkan variable likuiditas dan leverage tidak memberi pengaruh signifkan dan membentuk pola hubungan negative terhadap peringkat sukuk di lembaga perbankan syariah Indonesia penerbit sukuk.
\end{abstract}

Kata Kunci: Bank Umum Syariah; Rating sukuk; Rasio Keuangan.

\section{INTRODUCTION}

Based on the fatwa of the Indonesian Ulema Council (MUI) No. 32/ DSN-MUI/ IX/2002 concerning sukuk, which are bonds (long-term securities) with sharia principles created by companies which can then be purchased by the public provided that the company issuing the letter is required to provide profit sharing or in the form of margin. or a fee to the holder of the futures letter from its business activities and the company is willing to pay back the letter at a predetermined time (Obligasi Syariah (Sukuk), 2002). In practice, sukuk, which is a sharia form of conventional bonds, still uses several relevant features including equity but still adheres to sharia principles that avoid the practice of usury, gharar, and maysir. In investment activities, sukuk is an integral part of the ownership of tangible assets, wherefrom the results of this investment, the sukuk investor is entitled to a share of the financial contribution to the company in funding a particular project or financing run by the issuing institution (Cahyati \& Nurnasrina, 2019). In order to obtain a good image of the company so that the trust and loyalty of investors are high, it is necessary to rank the sukuk to find out that the issuer is worthy of being an investment object because of the creditworthiness and the institution issuing the sukuk. Islam does not rule out the possibility that sukuk may be exposed to the risk of default if the rating results show negative migration over several years of maturity measurement (Cahyati \& Nurnasrina, 2019).

The sukuk rating in the capital market world is important because it will be considered by investors in determining investment decisions, on the other hand, that the rating will provide 


\section{Tasharruf: Journal Economics and Business of Islam Vol. 6, No. 1 (2021):31-43 Website: http://journal.iain-manado.ac.id/index.php/TJEBI/index ISSN 2528-0325 (online) ISSN 2528-0317 (print)}

relevant information regarding the companies that issue sukuk, which will be in accordance with the main purpose of the sukuk rating, namely reducing the information asymmetry of issuers and investors (M. A. A. Elhaj et al., 2015). Issuers who issue sukuk must be assessed regularly every one period to find a picture that the creditability of the company is accountable and transparent, which will be beneficial for investors who do not have good capabilities in predicting the performance of the sukuk issuing company so that researchers try to analyze the factors that influence the performance of the sukuk issuing company. affect the high rating of sukuk starting from internal factors which include profitability, liquidity, leverage, and auditor reputation (Al Haraqi \& Ningsih, 2017; Melis, 2014; Pebruary, 2016), external factors, namely macro-economy and type of industry (Arundina et al., 2016), including the board of directors (M. A. Elhaj et al., 2018) and accountability in the presentation of financial statements (Qizam \& Fong, 2019).

Literature and empirical studies related to factors that can affect the rankings have been carried out by several researchers, but the results given indicate that there is an inconsistency of conclusions, among the researchers, namely: (Nurfa'izah et al., 2020) stated that profitability, leverage, security, and company size had an influence on the rating of sukuk, while different results were carried out by (Rofi, 2020) which gives the result that total assets and profitability have a positive and significant effect, while the productivity of issuers has no effect on the sukuk rating. Likewise in research (Fitriani et al., 2020) which concludes that only profitability has an effect on the sukuk rating, while liquidity has a negative effect, and solvency and company growth have no effect on the sukuk rating. The contradiction result is also given by (Rukmana \& Laila, 2020) which shows that Leverage, Profitability and the type of sukuk mudharabah have no effect on the sukuk rating, while the size of the company, liquidity, corporate governance, and the type of sukuk actually affect the probability of the sukuk rating.

Similar research that examines the ranking of sukuk was carried out by (Darmawan et al., 2020) only company size has no effect on the sukuk rating, while profitability, liquidity, leverage, and bondage have an effect. while (Cahyati \& Nurnasrina, 2019) shows that there is a positive and significant effect between profitability and leverage on the sukuk rating, while (Muhammad \& Biyantoro, 2019) has a conclusion that contradicts these results, where profitability and company size actually have an effect on the sukuk rating, while leverage has a negative relationship and company growth has no effect. On the other hand that (Juardi \& Sueno, 


\section{Tasharruf: Journal Economics and Business of Islam Vol. 6, No. 1 (2021):31-43 Website: http://journal.iain-manado.ac.id/index.php/TJEBI/index ISSN 2528-0325 (online) ISSN 2528-0317 (print)}

2019) also found that the productivity and size of the company that has an effect on the ranking of sukuk and maturity have no effect.

Based on previous research that shows inconsistencies in providing results related to factors that can influence the sukuk rating, further studies are needed to contribute empirically about the factors that affect the sukuk rating and fill the gaps by providing results that can strengthen or reject the results of previous research, so that This research will comprehensively discuss the factors that influence the rating of sukuk using variables, namely profitability ratios, liquidity ratios, leverage ratios, and productivity ratios. The main goal to be achieved by the researcher is to provide consistency of results on the sukuk rating using the object of study of Islamic commercial banks and specifically, this study examines the 2015-2019 period to find out what ratio factors contribute to the influence of the sukuk rating in the Islamic banking institution.

The basic theory used in this study is Agency theory and Signal theory, where agency theory gives the view that there is a possibility of conflicts of interest occurring between agents and users, which can be in the form of stock investors with internal institutions and or fellow investors, namely stock and sukuk investors (Borhan \& Ahmad, 2018), there is a possibility of conflict among investors because each of the investors has different interests and perspectives on the company or institution that issues the securities, where the perspective of the sukuk investor will review a prudent company, this is useful for the issuer's ability to pay at maturity so that avoid the risk of default, but on the contrary that the stock investor's point of view will view the company as good when it is able to provide high profits in the form of dividends and/or capital gains, where the company often bets with high risks for the sake of expansion and company profits (Lustig, 2014).

In addition to agency theory, another theory that can be used to look at sukuk ratings is signaling theory, where company stakeholders as the signaling management authority in the form of financial reports and relevant information related to the rating process at institutions appointed as sukuk ratings which will then be analyzed and calculated. and issued the rating results which are ready to be published to interested parties. The rating results illustrate that the company's ability to pay debts is in the form of signals of failure or fulfillment of obligations. Factors that are often used by researchers to determine the factors that have the most influence on the rating 


\section{Tasharruf: Journal Economics and Business of Islam Vol. 6, No. 1 (2021):31-43 Website: http://journal.iain-manado.ac.id/index.php/TJEBI/index ISSN 2528-0325 (online) ISSN 2528-0317 (print)}

of sukuk are profitability ratios, liquidity ratios, leverage ratios, and productivity ratios (Darmawan et al., 2020; Nurfa'izah et al., 2020).

The profitability ratio shows how much the company is able to earn a profit, where many researchers use this proxy as a variable that has a positive and significant influence on the rating of sukuk by using the rate of assets or return on return on assets (ROA), including: (Nurfa'izah et al., 2020) which examines the profitability of companies issued by PT PEFINDO using panel data regression analysis for five years, showing significant and positive results on the sukuk rating. By using ordinal logistic regression performed by (Fitriani et al., 2020) also shows that the profitability proxied by ROA shows a positive and significant relationship to the rating of sukuk. In line with the research, (Darmawan et al., 2020) testing 86 samples of companies using multiple linear regression concluded that sukuk ratings can be influenced by company profitability. Research that has similar results is (Afiani, 2013; Astuti, 2017; Cahyati \& Nurnasrina, 2019; Kartika Hendra Titisari, 2017; Kurniawan \& Suwarti, 2017; Muhammad \& Biyantoro, 2019; Pebruary, 2016; Pranoto et al., 2017; Tensia et al., 2015; Widowati et al., 2013), while the researchers who found that the profitability ratio had no effect on the sukuk rating were (Malia \& Andayani, 2015; Rukmana \& Laila, 2020). Based on the literature review above, this study hypothesizes that:

H1: Profitability has a significant effect on the rating of Sharia Banking Sukuk.

The liquidity ratio is an institution's ability to meet short-term debt obligations according to maturity, where researchers use this ratio to predict the fluctuation of the sukuk position by using the proxy Current Ratio (CR). (Murhardi, 2013) which shows that the ratio with the proxy has an influence on the sukuk rating, among the researchers, namely (Cahyati \& Nurnasrina, 2019) by using panel data regression for five years with seven companies that the liquidity ratio has an influence on sukuk ratings, this is also supported by research results (Darmawan et al., 2020) which gives similar results that by analyzing a larger sample of 86 companies and the same analytical tool that the CR proxy has a positive and significant effect on the sukuk rating. With ordinal logistic regression analysis tools and 64 samples of issuers of sukuk that were studied by (Melinda \& Wardani, 2018) shows the conclusion that the liquidity ratio has a positive and significant influence on the sukuk rating. Other researchers who have similar results, namely the liquidity ratio has an effect on the sukuk rating, namely: (Kurniawan \& 


\section{Tasharruf: Journal Economics and Business of Islam Vol. 6, No. 1 (2021):31-43 Website: http://journal.iain-manado.ac.id/index.php/TJEBI/index ISSN 2528-0325 (online) ISSN 2528-0317 (print)}

Suwarti, 2017; Muhammad \& Biyantoro, 2019; Nurfa'izah et al., 2020; Pebruary, 2016; Tensia et al., 2015; Widowati et al., 2013), while different results where this ratio has no effect on the rating of sukuk have been produced by (Afiani, 2013; Hamida, 2017; Rukmana \& Laila, 2020). Based on previous research that this study has a hypothesis, namely:

$\mathrm{H} 2$ : Liquidity has a significant effect on the rating of Islamic banking sukuk.

Leverage is the Solvency Ratio which is the company's ability to meet and maintain all debt obligations when they are due, where a lot of research has been produced by researchers showing that the sukuk rating can be predicted by the amount of leverage with the proxy Debt to Asset Ratio (DAR) (Hamida, 2017) Among these researchers, namely (Muhammad \& Biyantoro, 2019) which tested 15 companies with multiple regression models as an analytical tool that gave positive results and significantly affected the sukuk rating. On the other hand, using factor analysis and logistic regression analysis on 163 samples of bonds resulted that bond ratings can be influenced by the DAR proxy. Research that gives the same conclusions include: (Cahyati \& Nurnasrina, 2019; Darmawan et al., 2020; Kartika Hendra Titisari, 2017; Kurniawan \& Suwarti, 2017; Malia \& Andayani, 2015; Melinda \& Wardani, 2018; Nurfa'izah et al., 2020; Pebruary, 2016; Tensia et al., 2015). While the results which conclude that leverage does not contribute to the sukuk rating have been carried out by (Afiani, 2013; Fitriani et al., 2020; Hamida, 2017; Rukmana \& Laila, 2020). Based on the study of several researchers related to the rating of sukuk, this study has a hypothesis that:

H3: Leverage has a significant effect on sukuk ratings

Productivity Ratio as measured by Total Asset Turn Over (TATO) is a ratio to assess how effective a company or banking institution is in maximizing its financial resources to increase output or profit, where many researchers have used this proxy as a variable that can also affect the rating of sukuk (Afiani, 2013), Among researchers who show that there is a relationship between the two are as follows: (Kartika Hendra Titisari, 2017) who tested 14 sukuk issuing companies using multiple regression resulted that the productivity ratio had a positive and significant influence on the sukuk rating, the next researchers who had the same result were (Pranoto et al., 2017) who has tested the ordinal logistic regression model using 35 selected samples that the TATO proxy has a positive and significant relationship with the rating of sukuk. Other researchers who have similar results are: (Astuti, 2017; Hadinata, 2020; Juardi \& Sueno, 


\section{Tasharruf: Journal Economics and Business of Islam Vol. 6, No. 1 (2021):31-43 Website: http://journal.iain-manado.ac.id/index.php/TJEBI/index ISSN 2528-0325 (online) ISSN 2528-0317 (print)}

2019; Rofi, 2020; Widowati et al., 2013), while the research that gave different results, namely the effect of the TATO proxy on the sukuk rating was carried out by (Afiani, 2013; Kurniawan \& Suwarti, 2017; Malia \& Andayani, 2015; Tensia et al., 2015). Based on the discussion and study results of several studies, this research formulates the following hypotheses:

H4: Productivity has a significant effect on sukuk ratings

\section{RESEARCH METHOD}

This study is a quantitative study that uses the entire population of Islamic banking issuing sukuk, where purposive sampling is used as a sampling method with certain provisions and criteria made so as to produce six selected Islamic banking institutions which are then analyzed within a period of five years using the SPSS statistical tool. . Multiple linear regression is used as a data analysis technique to determine how much influence the independent variable has on the dependent variable of sukuk ranking. Where the regression model formed is as follows:

$\mathrm{Y}=\mathrm{a}+\mathrm{b} 1 \mathrm{X} 1+\mathrm{b} 2 \mathrm{X} 2+\mathrm{b} 3 \mathrm{X} 3+\mathrm{b} 4 \mathrm{X} 4+\mathrm{e}$

Gloss:

Y : Sukuk Rating in Islamic Banking

a : Constant, that is the value of sukuk rating if the independent variable is 0

b1-b4 : Regression coefficient of independent variable

X : Profitability

X2 : Liquidity

X3 : Leverage

X4 : Productivity

The ranking of sukuk in this study is based on companies licensed by the capital market and financial institution supervisory agency (BAPEPAM-LK), namely PT. Pefindo that rates sukuk in two divisions, where the values of AAA, AA, BBB are categorized as Investment Grade while those grouped as non-investment grades have BB, B, CCC, D ratings. so that it is quantified based on PT Pefindo's interval scale. 
Tasharruf: Journal Economics and Business of Islam Vol. 6, No. 1 (2021):31-43

Website: http://journal.iain-manado.ac.id/index.php/TJEBI/index

ISSN 2528-0325 (online) ISSN 2528-0317 (print)

\section{RESULT AND DISCUSSION}

Table 1. Descriptive Analysis

\begin{tabular}{|l|c|}
\hline Sample Assessment Criteria & Number \\
\hline Sharia Commercial Banks & 14 \\
BUS does not issue Sukuk & $(8)$ \\
Sharia Banking Institutions Issuers of Sukuk & 6 \\
Selected Sample for five periods & 30 \\
\hline
\end{tabular}

Data Source: Processed in 2021

Table 2. Multiple Linear Regression Test

\begin{tabular}{|c|c|c|c|c|c|}
\hline \multirow[b]{2}{*}{ Mode } & & \multicolumn{2}{|c|}{ Unstandardized Coefficients } & \multirow[b]{2}{*}{$\mathrm{t}$} & \multirow[b]{2}{*}{ Sig } \\
\hline & & B & Std. Error & & \\
\hline \multirow[t]{7}{*}{1} & (Constant) & 13.948 & 3.385 & 4.121 & .000 \\
\hline & Profitabilitas (ROA) & .141 & .129 & 1.094 & .284 \\
\hline & Rasio Likuiditas (CR) & -.002 & .046 & -.052 & .959 \\
\hline & Leverage (DAR) & -.062 & .026 & -2.413 & .023 \\
\hline & Productivity (TATO) & .915 & .219 & 4.174 & .000 \\
\hline & Adjusted R Square & .552 & & & \\
\hline & F- Statistics & 9.951 & & & .000 \\
\hline
\end{tabular}

Data Source: Processed in 2021

Based on the results of the regression test with the help of the SPSS 23 statistical tool in table 2 above, it shows that the ability of all independent variables to explain the dependent variable is $55.2 \%$. On the other hand, the result of the simultaneous test is that the calculated $\mathrm{F}$ value is 9.951 greater than $\mathrm{f}$ table $(\mathrm{F}$ table $=2.62)$ and the significance level test is less than 0.05 (ie 0.00), so the regression model used is feasible and meets the test requirements. Therefore the regression model formed is as follows:

$\mathrm{Y}=13.948+0.141 \mathrm{ROA}-002 \mathrm{CR}-0.62 \mathrm{DAR}+0.915 \mathrm{TATO}+\mathrm{e}$

Based on this equation, it can be explained that the profitability coefficient is positive which indicates that there is a unidirectional relationship, where when the ROA value is increased by $1 \%$ and other variables are assumed to be constant, the sukuk rating will increase by $1 \%$. The results of the t-test indicate that the significance of profitability exceeds 0.05 , which is 0.284 and the t-table value is $1.094<\mathrm{t}$-table, which is 2.059 , so that the conclusion of the 


\section{Tasharruf: Journal Economics and Business of Islam Vol. 6, No. 1 (2021):31-43 Website: http://journal.iain-manado.ac.id/index.php/TJEBI/index ISSN 2528-0325 (online) ISSN 2528-0317 (print)}

hypothesis, namely $\mathrm{H} 1$ is not accepted, which means that profitability has no effect on the sukuk rating.

The indication contributed is that the higher the profitability of Islamic banking institutions, the potential to increase the sukuk rating, but the test results show that there is no significant effect on the dependent variable. This is in accordance with research conducted by Malia \& Andayani, 2015; Rukmana \& Laila, 2020) which shows that the profitability variable has no influence on the sukuk rating of Islamic banking institutions.

While the liquidity coefficient shows a negative sign which means that there is an opposite relationship where every increase in the $\mathrm{CR}$ value in banking institutions will reduce the sukuk rating number if other variables are held constant. If viewed from the partial test, the significance value obtained is 0.959 , which means that it is greater than the significance number used, which is 0.05 , while the $t$ arithmetic obtained is -.052 , while the $t$ table obtained is 2.059 so that $\mathrm{H} 2$ is not accepted. means that the liquidity variable proxied by the current ratio does not have a significant effect on the sukuk rating in Islamic banking institutions.

Therefore, the liquidity ratio indicates that any increase will have a negative impact on the sukuk rating in Islamic banking institutions. This research strengthens the previous research, namely: (Afiani, 2013; Hamida, 2017; Rukmana \& Laila, 2020), which concludes the study that the liquidity ratio has no effect on the sukuk rating.

A negative coefficient also occurs in the solvency ratio or leverage, which indicates that there is a reverse relationship with the achievement of the sukuk rating, i.e. if there is an increase in the DAR proxy, this will potentially lower the sukuk rating in Islamic banking institutions with the assumption that other variables are zero. The results of the t-test indicate that the t-count obtained is -2.413 , the gain is smaller than the t-table which is 2.059 and the significance value of this ratio is greater than alpha $(0.23>0.05)$ which indicates a rejection of $\mathrm{H} 3$ which means that leverage has no effect on the rating of sukuk in Indonesian Islamic banking institutions.

Indications that can be concluded that every time there is an increase in one unit number in leverage, it will reduce the sukuk rating, this research is in line with research conducted by (Afiani, 2013; Fitriani et al., 2020; Hamida, 2017; Rukmana \& Laila, 2020) which shows that there is no effect on the leverage variable on the sukuk rating. 


\section{Tasharruf: Journal Economics and Business of Islam Vol. 6, No. 1 (2021):31-43 Website: http://journal.iain-manado.ac.id/index.php/TJEBI/index ISSN 2528-0325 (online) ISSN 2528-0317 (print)}

The variable that gives a positive direction besides profitability is the productivity ratio which is proxied by the TATO ratio. This shows that any increase that occurs in this ratio will have a good impact on the sukuk rating which will also increase with the assumption that other variables are considered not to have contributed to the sukuk rating. Based on the results of the $\mathrm{t}$ test, it shows that the $t$ count is $4.174>2.059$ and the significance value obtained is $0.00<0.05$, which means that the productivity ratio has a positive and significant effect on the rating of sukuk in Islamic banking institutions so that $\mathrm{H} 4$ can be accepted where the ratio with the TATO proxy has an effect on the sukuk rating.

The results of this study indicate that every 1 percent increase in the meal productivity ratio raises the sukuk rating because it has a unidirectional relationship. This is also mentioned in the results of research conducted by (Astuti, 2017; Hadinata, 2020; Juardi \& Sueno, 2019; Rofi, 2020; Widowati et al., 2013) Kartika Hendra Titisari, 2017) (Pranoto et al., 2017) which shows that the productivity variable has a positive and significant effect on the sukuk rating.

\section{CONCLUSION}

The purpose of this research is to discuss the effect of profitability ratios, liquidity ratios, leverage, and productivity ratios on sukuk ratings in Islamic banking institutions issuing sukuk. Based on the test results and data analysis shows that only the productivity variable has a significant and positive effect on the sukuk rating in Islamic banking institutions, although it has a positive coefficient, profitability does not have a significant effect on the sukuk rating. while the variables of liquidity and leverage do not have a significant effect and form a negative relationship pattern on the rating of sukuk in Indonesian Islamic banking institutions that issue sukuk.

\section{REFERENCES}

Afiani, D. (2013). Pengaruh Likuiditas, Produktifitas, Profitabilitas, dan Leverage Terhadap Peringkat Sukuk (Studi Empiris pada Bank Umum Syariah dan Unit Usaha Syariah Periode 2008-2010). Accounting Analysis Journal, 2(1).

Al Haraqi, M. S., \& Ningsih, E. S. (2017). Pengaruh Return on Asset, Secure dan Maturity Terhadap Rating Sukuk. Jurnal Ilmiah Mahasiswa Ekonomi Akuntansi, 2(4), 116-124. 


\section{Tasharruf: Journal Economics and Business of Islam Vol. 6, No. 1 (2021):31-43 Website: http://journal.iain-manado.ac.id/index.php/TJEBI/index ISSN 2528-0325 (online) ISSN 2528-0317 (print)}

Arundina, T., Kartiwi, M., \& Omar, M. A. (2016). Artificial Intelligence for Islamic Sukuk Rating Predictions. In Artificial Intelligence in Financial Markets. Palgrave Macmillan.

Astuti, R. P. (2017). PENGARUH LIKUIDITAS, PRODUKTIVITAS, PROFITABILITAS, TERHADAP PERINGKAT SUKUK Ratna Puji Astuti Magister Akuntansi, STIE Darmaputra Semarang. Jurnal Ilmu Manajemen Dan Akuntansi Terapan (JIMAT), 8(1), 8094.

Borhan, N. A., \& Ahmad, N. (2018). Identifying the determinants of Malaysian corporate Sukuk rating. International Journal of Islamic and Middle Eastern Finance and Management, $11(3), 432-448$.

Cahyati, A., \& Nurnasrina, N. (2019). Peringkat Sukuk Berdasarkan Return on Asset dan Debt to Equity Ratio. SERAMBI: Jurnal Ekonomi Manajemen Dan Bisnis Islam, 1(3), 101-110. https://doi.org/10.36407/serambi.v1i3.132

Darmawan, A., Al Fayed, Y. F., Bagis, F., \& Pratama, B. C. (2020). Pengaruh Profitabilitas, Likuiditas, Leverage, Umur Obligasi Dan Ukuran Perusahaan Terhadap Peringkat Obligasi Pada Sektor Keuangan Yang Terdapat Di Bei Tahun 2015-2018. DERIVATIF: Jurnal Manajemen, 14(1), 99-114. https://doi.org/10.24127/jm.v14i1.443

Obligasi Syariah (Sukuk), 32 (2002).

Elhaj, M. A. A., Muhamed, N. A., \& Ramli, N. M. (2015). The influence of corporate governance, financial ratios, and Sukuk structure on Sukuk rating. Procedia Economics and Finance, 31, 62-74.

Elhaj, M. A., Muhamed, N. A., \& Ramli, N. M. (2018). The effects of board attributes on Sukuk rating. International. Journal of Islamic and Middle Eastern Finance and Management, $11(2), 312-330$.

Fitriani, P. R., Andriyanto, I., \& Ridwan, M. (2020). Pengaruh Rasio Keuangan dan Pertumbuhan Perusahaan Terhadap Peringkat Obligasi Syariah. AKTSAR: Jurnal Akuntansi Syariah, 3(1), 103-118. https://doi.org/10.21043/aktsar.v3i1.7629

Hadinata, S. (2020). Determinan Peringkat Sukuk: Ditinjau dari Aspek Akuntansi dan Non- 


\section{Tasharruf: Journal Economics and Business of Islam Vol. 6, No. 1 (2021):31-43 Website: http://journal.iain-manado.ac.id/index.php/TJEBI/index ISSN 2528-0325 (online) ISSN 2528-0317 (print)}

Akuntansi. Wahana Riset Akuntansi, 8(2), 95-107.

Hamida, L. (2017). PENGARUH LIKUIDITAS DAN LEVERAGE TERHADAP YIELD SUKUK DENGAN PERINGKAT SUKUK SEBAGAI VARIABEL INTERVENING (Study Pada Perusahaan Non Keuangan di Bursa Efek Indonesia ). Jurnal Ekonomi Dan Bisnis, 18(1), 71-86. https://doi.org/10.30659/ekobis.18.1.71-86

Juardi, \& Sueno, N. (2019). Pengaruh Produktivitas , Firm Size dan Maturity Terhadap Peringkat Sukuk Pada Perusahaan Non Keuangan Di Indonesia. AKRUAL Jurnal Akuntansi Dan Keuangan, 1(2), 1-18.

Kartika Hendra Titisari, E. W. S. N. (2017). Pengaruh Rasiolikuiditas, Rasio Produktivitas, Rasio Profitabilitas, Dan Rasio Solvabilitas Terhadap Peringkat Sukuk. Jurnal Akuntansi Dan Pajak, 18(01), 130-139. https://doi.org/10.29040/jap.v18i01.90

Kurniawan, A. T., \& Suwarti, T. (2017). Pengaruh profitabilitas, leverage, likuditas dan produktifitas terhadap peringkat obligasi. Prosiding Seminar Nasional Multi Disiplin Ilmu \&Call for Papers Unisbank Ke-3, 3(3), 435-443.

Lustig, Y. (2014). The Investment Assets Handbook: A Definitive Practical Guide to Asset Classes. Harriman House Limited.

Malia, L., \& Andayani. (2015). Pengaruh Rasio Keuangan Terhadap Peringkat Sukuk. Jurnal Ilmu \& Riset Akuntansi, 4(11), 1-15.

Melinda, D., \& Wardani, M. K. (2018). Faktor-faktor yang mempengaruhi peringkat sukuk pada perushaan penerbit sukuk di Bursa Efek Indonesia. KOMPARTEMEN: Jurnal Ilmiah Akuntansi, 17(2), 69-90.

Melis, K. (2014). Analisis Faktor-Faktor yang Mempengaruhi Rating Sukuk. Jurnal Ilmiah Mahasiswa FEB Universitas Brawijaya, 3(1), 1-21.

Muhammad, R., \& Biyantoro, C. T. S. (2019). Faktor-Faktor Yang Mempengaruhi Peringkat Sukuk (Studi Empiris Perusahaan Yang Diperingkat Fitch Rating). Al-Masraf: Jurnal Lembaga Keuangan Dan Perbankan, 4(2), 187-200. https://doi.org/10.15548/almasraf.v4i2.267 


\section{Tasharruf: Journal Economics and Business of Islam Vol. 6, No. 1 (2021):31-43 Website: http://journal.iain-manado.ac.id/index.php/TJEBI/index ISSN 2528-0325 (online) ISSN 2528-0317 (print)}

Murhardi, W. R. (2013). Analisis Laporan Keuangan, Proyeksi dan Valuasi Saham. Salemba Empat.

Nurfa'izah, Kaukab, M. E., \& Efendi, B. (2020). PERATINGAN SUKUK Nurfa' izah, M . Elfan Kaukab, Bahtiar Efendi. Manarul Qur'an:Jurnal Ilmiah Studi Islam, 20(1), 20-34.

Pebruary, S. (2016). LEVERAGE DAN PENDAPATAN BUNGA TERHADAP RATING SUKUK KORPORASI PERIODE 2010-2013 Silviana Pebruary Universitas Islam Nahdlatul Ulama Jepara Email : pebruary.silvi02@gmail.com. Dinamika Ekonomi \& Bisnis, 13(1), 95-112.

Pranoto, G. E., Anggraini, R., \& Takidah, E. (2017). Pengaruh Profitabilitas, Ukuran Perusahaan, Produktivitas, Dan Reputasi Auditor Terhadap Peringkat Sukuk. Jurnal Wahana Akuntansi, 12(1), 13. https://doi.org/10.21009/wahana.012/1.2

Qizam, I., \& Fong, M. (2019). Developing financial disclosure quality in sukuk and bond market: Evidence from Indonesia, Malaysia, and Australia. Borsa Istanbul Review, 19(3), $228-248$.

Rofi, A. T. (2020). Pengaruh Total Assets Dan Total Assets Turnover Terhadap Rating Sukuk Dengan Return On Assets Sebagai Variabel Intervening Studi Pada Sukuk Korporasi Di Indonesia Tahun 2016-2018. Islamic Economics Journal, 6(1), 1-26. https://doi.org/10.21111/iej.v6i1.4451

Rukmana, A. D., \& Laila, N. (2020). Pengaruh Ukuran Perusahaan, Likuiditas, Leverage, Profitabilitas, Corporate Governance, Dan Jenis Sukuk Terhadap Rating Sukuk Korporasi Di Indonesia. Jurnal Ekonomi Syariah Teori Dan Terapan, 7(9), 1786-1803. https://doi.org/10.20473/vol7iss20209pp1786-1803

Tensia, K. O., Yaya, R., \& Supriyono, E. (2015). Variabel - Variabel Yang Dapat Memengaruhi Peringkat Obligasi (Studi Kasus Perusahaan Non Keuangan dan Non Jasa yang Terdaftar di Bursa Efek Indonesia). JBTI : Jurnal Bisnis Teori Dan Implementasi, 6(2), 184-206.

Widowati, D., Nugrahanti, Y., \& Kristanto, A. B. (2013). Analisis Faktor Keuangan dan Non Keuangan yang Berpengaruh pada Prediksi Peringkat Obligasi di Indonesia. Jurnal Manajemen, 13(1), 35-54. 